\title{
Effect of Foliar Application of Nutrients and Plant Growth Regulators on Quality Parameters of Guava (Psidium guajava L.) Fruit cv. Lalit
}

\author{
Akash Shukla, R.S. Verma*, Som Prakash, Dharmpal Singh and Rajesh Kumar \\ Department of Horticulture, Babasaheb Bhimrao Ambedkar University (A Central University) \\ Vidya Vihar, Rae Bareli Road, Lucknow-226025 (U.P.) India \\ *Corresponding author
}

A B S T R A C T

\begin{tabular}{|c|}
\hline Keywords \\
\hline $\begin{array}{l}\text { Guava, Urea, } \\
\text { Potassium sulphate, } \\
\text { Zinc sulphate, GA3, } \\
\text { NAA and Quality } \\
\text { parameters }\end{array}$ \\
\hline Article Info \\
\hline $\begin{array}{l}\text { Accepted: } \\
\text { 10 April } 2019 \\
\text { Available Online: } \\
10 \text { May } 2019\end{array}$ \\
\hline
\end{tabular}

A field experiment was conducted during 2017 at Horticulture Research Farm-1, BBAU, Lucknow on 11- year- old guava plants, Studies on the Effect of foliar application of nutrients and plant growth regulators on quality parameters of guava (Psidium guajava L.) fruit cv. Lalit", revealed that T.S.S $\left({ }^{0} \mathrm{~B}\right)$, reducing sugar, non-reducing sugar, total sugars, ascorbic acid and acidity were maximized when foliar spray was done with Urea (1\%), Potassium sulphate (1\%), Zinc sulphate (1\%) $\mathrm{GA}_{3} 50 \mathrm{ppm}$, and NAA $50 \mathrm{ppm}$.

\section{Introduction}

Guava (Psidium guajava L.) is the apple of the tropics, is one of the most popular fruits grown in tropical, sub-tropical and some parts of arid regions of India. Guava belongs to the family Myrtaceae. It has been in cultivation in India since 17th century and has originated in tropical America perhaps from Mexico to Peru and introduced in India by Portuguese. It can withstand drought up to some extent but only few degrees of frost. The importance of guava is due to the fact that it is a hardy fruit and which can be grown in poor alkaline soil or poorly drained soils and $\mathrm{pH} 8.5$, it can with stand to the maximum temperature at $46^{\circ} \mathrm{c}$ and annual rainfall of less than $25 \mathrm{~mm}$. Guava fruits are also used for preparation of jam, jelly, RTS, nectar etc. The guava bears flowers and fruits on current season growing twinges and highly cross-pollinated crop and pollination occurs through honey bees and andirona insect, fruit of guava developed from inferior ovary on exhibited double sigmoid growth curve, fruit with many seed berry, the fruit take nearly 4-5 month from dark green to yellowish green. The common guava is a diploid $2 \mathrm{n}=22$, but natural and artificial 
triploid $(2 n=33)$ and aneuploid exist triploid generally produce seedless fruit. In northern India guava plant bears flower twice or sometimes thrice in a year. The spring flowering is called "AmbeBahar" June or monsoon flowering is called "MrigBahar" and third flowering which comes in October is called "Hast Bahar" AmbeBahar fruit ripen from July to September and MrigBahar fruit ripen in from November to February, however, Hast Bahar fruit ripen in spring season, which also known as summer season crop.

\section{Materials and Methods}

11- year- old uniform guava plants of Lalit cultivar planted at $6 \times 6 \mathrm{~m}$ a part growing in Horticulture Research Farm-1 of Babasaheb Bhimrao Ambedkar University Lucknow226025 were taken for the investigation. $\mathrm{T}_{1}$ (Urea 1\%), $\mathrm{T}_{2}$ (Potassium sulphate $1 \%$ ), $\mathrm{T}_{3}$ (Zinc sulphate $1 \%), \mathrm{T}_{4}\left(\mathrm{GA}_{3} 50 \mathrm{ppm}\right), \mathrm{T}_{5}$ (NAA 50ppm), $\mathrm{T}_{6}$ (Urea 1\%+ NAA 50ppm), $\mathrm{T}_{7}$ (Urea $1 \%+\mathrm{GA}_{3} 50 \mathrm{ppm}$ ), $\mathrm{T}_{8}$ (Urea $1 \%+$ Zinc sulphate 1\%), $\mathrm{T}_{9}$ (Urea 1\%+ Potassium sulphate $1 \%$ ) along with $\mathrm{T}_{0} \mathrm{~W}$ ater spray (control).

First spraying of micro nutrients and plant growth regulators were done before flowering (first week of August) and second after fruit set (second week of September) during 2017. The experiment was laid out in R.B.D. with three replications. Observations recorded to be T.S.S $\left({ }^{0} \mathrm{~B}\right)$, Reducing sugar, Non-reducing sugar, Total sugars, Ascorbic acid and Acidity. The data so obtained were analysed statically.

\section{Results and Discussion}

A perusal of data presented in Table 1 shows that significant response in the maximum TSS content was observed due to treatment urea $1 \%+$ NAA $50 \mathrm{ppm}\left(\mathrm{T}_{6}\right)$ followed by $\left(11.26^{0}\right.$ Brix) urea $1 \%+\mathrm{GA}_{3} 50 \mathrm{ppm}\left(\mathrm{T}_{7}\right)$. while minimum TSS content was recorded in control (water spray) $\mathrm{T}_{0}$. The TSS contents of guava fruits varied from 7.66 to 12.09 in control.

The maximum reducing sugar content (3.91\%) was obtained with foliar application of urea $1 \%$ + NAA $50 \mathrm{ppm}\left(\mathrm{T}_{6}\right)$, followed by $(3.72 \%)$ urea $1 \%+\mathrm{GA}_{3} 50 \mathrm{ppm}\left(\mathrm{T}_{7}\right)$. The minimum value $(2.88 \%)$ was found in control $\left(\mathrm{T}_{0}\right)$. The reducing sugar contents of guava fruits varied from 2.88 to 3.91 in control.

The highest non-reducing sugar content $(3.56 \%)$ was measured with the foliar application of urea $1 \%+\mathrm{NAA} 50 \mathrm{ppm}\left(\mathrm{T}_{6}\right)$, followed by $(3.34 \%)$ urea $1 \%+\mathrm{GA}_{3} 50 \mathrm{ppm}$ $\left(\mathrm{T}_{7}\right)$. The minimum value $(2.95 \%)$ was found in control $\left(\mathrm{T}_{0}\right)$. The results, further, advocated that higher concentration of all treatments proved effective as compared to the lower concentrations.

The maximum total sugars content of fruit (7.72\%) was recorded with foliar application of urea $1 \%$ + NAA $50 \mathrm{ppm}\left(\mathrm{T}_{6}\right)$, followed by $(7.08 \%)$ urea $1 \%+\mathrm{GA}_{3} 50 \mathrm{ppm}\left(\mathrm{T}_{7}\right)$. The minimum value $(5.87 \%)$ was found in control $\left(\mathrm{T}_{0}\right)$.

The highest ascorbic acid (172.07mg/100g fruit pulp) was recorded with higher concentration of urea $1 \%$ + NAA 50 ppm $\left(\mathrm{T}_{6}\right)$, followed by $(168.42 \mathrm{mg} / 100 \mathrm{~g}$ fruit pulp) urea $1 \%+\mathrm{GA}_{3} 50 \mathrm{ppm}\left(\mathrm{T}_{7}\right)$. The lowest $(158.45 \mathrm{mg} / 100 \mathrm{~g}$ fruit pulp) under control $\left(\mathrm{T}_{0}\right)$.

The minimum acidity was recorded with the application of urea $1 \%+$ NAA $50 \mathrm{ppm}\left(\mathrm{T}_{6}\right)$, followed by $(0.56 \%)$ urea $1 \%+\mathrm{GA}_{3} 50 \mathrm{ppm}$ $\left(\mathrm{T}_{7}\right)$.However, produced significantly less acidic fruits when compared with rest of the treatments. The fruits under control gave significantly maximum control (water spray) $\mathrm{T}_{0}$. 
Table.1 Effect of foliar application of nutrients and plant growth regulators on quality parameters of guava (Psidium guajava L.) fruit cv. Lalit"

\begin{tabular}{|c|c|c|c|c|c|c|}
\hline Treatments & $\begin{array}{l}\text { T.S.S } \\
\left({ }^{0} \mathbf{B}\right)\end{array}$ & $\begin{array}{l}\text { Reducing } \\
\text { sugar(\%) }\end{array}$ & $\begin{array}{c}\text { Non- } \\
\text { reducing } \\
\operatorname{sugar}(\%)\end{array}$ & $\begin{array}{c}\text { Total } \\
\text { sugars } \\
(\%)\end{array}$ & $\begin{array}{l}\text { Ascorbic } \\
\text { acid(mg/1 } \\
\text { 00g) }\end{array}$ & $\begin{array}{l}\text { Acidity } \\
(\%)\end{array}$ \\
\hline $\mathbf{T}_{0}($ Control $)$ & 7.66 & 2.88 & 2.95 & 5.87 & 158.45 & 0.68 \\
\hline$T_{1}($ Urea $1 \%)$ & 9.02 & 3.08 & 3.00 & 6.32 & 162.55 & 0.65 \\
\hline $\mathrm{T}_{2}$ (Potassium sulphate $\left.1 \%\right)$ & 9.75 & 3.12 & 3.07 & 6.44 & 163.31 & 0.61 \\
\hline $\mathbf{T}_{3}$ (Zinc sulphate $\left.1 \%\right)$ & 9.29 & 3.16 & 3.10 & 6.53 & 164.34 & 0.65 \\
\hline $\mathrm{T}_{4}\left(\mathrm{GA}_{3} 50 \mathrm{ppm}\right)$ & 9.62 & 3.59 & 3.21 & 6.61 & 165.49 & 0.57 \\
\hline $\mathrm{T}_{5}(\mathrm{NAA}$ 50ppm) & 10.42 & 3.18 & 3.20 & 6.67 & 164.38 & 0.58 \\
\hline $\mathrm{T}_{6}($ Urea $1 \%$ + NAA 50ppm) & 12.09 & 3.91 & 3.56 & 7.20 & 172.07 & 0.51 \\
\hline $\mathrm{T}_{7}\left(\right.$ Urea $1 \%+\mathbf{G A}_{3}$ 50ppm $)$ & 11.26 & 3.72 & 3.34 & 7.08 & 168.43 & 0.56 \\
\hline $\begin{array}{l}T_{8} \text { (Urea } 1 \%+\text { Zinc sulphate } \\
1 \% \text { ) }\end{array}$ & 10.81 & 3.63 & 3.13 & 6.85 & 166.35 & 0.66 \\
\hline $\begin{array}{l}\mathrm{T}_{9}(\text { Urea } 1 \%+\text { Potassium } \\
\text { sulphate } 1 \%)\end{array}$ & 10.82 & 3.20 & 3.10 & 6.56 & 165.96 & 0.61 \\
\hline S.Em. \pm & 0.167 & 0.133 & 0.071 & 0.132 & 1.043 & 0.025 \\
\hline C.D. at $5 \%$ & 0.501 & 0.399 & 0.214 & 0.395 & 3.122 & 0.076 \\
\hline
\end{tabular}

In conclusion, the quality parameters of fruit with respect T.S.S $\left({ }^{0} \mathrm{~B}\right)$, Reducing sugar, nonreducing sugar, Total sugar, Ascorbic acid and Acidity were obtained maximum with the foliar spray of urea $1 \%+$ NAA $50 \mathrm{ppm}\left(\mathrm{T}_{6}\right)$. Therefore, combined spray of urea $1 \%+$ NAA $50 \mathrm{ppm}\left(\mathrm{T}_{6}\right)$ can be advocated to guava growers for serving higher yield and better of quality of fruits.

\section{References}

Ali, W.; Pathak, R.A. and Yadav, A.L. (1993). Effect of foliar application of nutrients on guava (Psidium guajava $\mathrm{L}$.) cv. Allahabad Safeda. Prog. Hort., 23 (1-4): 14-21.

Awasthi, Priya and Lal, S. (2009). Effect of calcium, boron and zinc foliar sprays on the yield and quality of guava (Psidium guajava L.) Pantnagar J. Res., 7 (2): 223-225.

Ingle, K.G.; Khan, M.A.H. and Kshirsagar, R.E. (1993). Effect of foliar application of nutrients on yield and quality of guava (Psidium guajava L.) cv. L-49.
P.K.V. Res. J., 17 (1) 78- 80.

Jain, B.P.; Das, S.R. and Verma, S.K. (1985). Effect of growth substances and major elements on the synthesis of major chemical constituents of litchi (Litchi chinensis). Haryana J. Hort. Sci.,14 (12):1-3.

Joon, N.S.; Singh, R.R., and Daulta, B.S. (1984). Effect of foliar sprays of zinc and urea on yield and physico-chemical composition of ber fruits cv. Gola Haryana J. Hort. Sci., 13(3-4): 110112.

Kumar, S.; Kumar, S. and Verma, D.K. (2004). Effect of micro-nutrients and NAA on yield and quality of Litchi [Litchi chinensis (Gaertn) Sonn]cv. Dehradun. Abst in Proc. of International Seminar on Rec. Trend in Hi-Tech Hort. And PHT, originated by C.S.A.U.A. \& T., Kanpur, February 4-6: 193.

Rachna and Singh, S. (2013). Effect of gibberellic acid on periodical changes in bio-chemical composition of ber cv. Umran. Hort Flora Research Spectrum, 2 (1): 25-29. 
Singh, P.N. and Chhonkar, V.S. (1983). Effect of zinc, boron and molybdenum as foliar spray on chemical composition of guava fruit. Punjab Hort. J., 23 (1-2): 34-37.

\section{How to cite this article:}

Akash Shukla, R.S. Verma, Som Prakash, Dharmpal Singh and Rajesh Kumar. 2019. Effect of Foliar Application of Nutrients and Plant Growth Regulators on Quality Parameters of Guava (Psidium guajava L.) Fruit cv. Lalit. Int.J.Curr.Microbiol.App.Sci. 8(05): 956-959. doi: https://doi.org/10.20546/ijcmas.2019.805.111 